\title{
A Study on Performance Evaluation of Mixed Light Shelf Type According to the Angle of Light Shelf
}

\author{
Woori Chae ${ }^{1.1}$, Heangwoo Lee $e^{2.1}$ and Yongseong Kim ${ }^{2.2}$ \\ ${ }^{1}$ The Graduate School of Techno Design Kookmin University, \\ Jeongneung-dong, Seongbuk-gu, Seoul, 136-702, Korea \\ ${ }^{2}$ The Graduate School of Techno Design Kookmin University, \\ Jeongneung-dong, Seongbuk-gu, Seoul, 136-702, Korea \\ woori1983@nate.com ${ }^{1.1}$,moonup2001@nate.com ${ }^{2.1}$,yongkim@kookmin.ac.kr.2
}

\begin{abstract}
A light-shelf, one of natural lighting methods, has advantages in constructability and economic feasibility in comparison with other passive natural lighting system. A movable light-shelf enables a user in a room to adjust the angle according to his or her preference to control the amount of indoor light. In addition, a light-self serves as a shield to the intense light on window sides when the solar light is strong to relieve glare. The purpose of this study was to investigate the effect of angle adjustment of a mixed type light-shelf on indoor natural lighting and determine efficient light-shelf lighting performance values by using an actual size test-bed. This study was conducted in the following procedures: 1) Previous studies were investigated to analyze the definition of a light-shelf and identify experimental factors for a light-shelf; 2) On the basis of previous studies, the light-shelf experimental factors were set up with reference to the illumination values under clear sky at the meridian transit altitude in each season to perform an experiment; and 3) The performance of the light-shelf was evaluated to examine the effectiveness. The performance evaluation was performed for each season according to the solar altitude of the mixed light-shelf. The indoor distribution of illumination was analyzed on the basis of the day light introduction depending on the angle of the mixed type light-shelf to verify the correlation with variables and the efficacy.
\end{abstract}

Keywords: Light Shelf, Daylighting Performance, illumination

\section{Introduction}

\subsection{Background and Purpose}

As the issues of climate change and global warming come to the fore, energy consumption inside buildings is continuously increased. Therefore, more concerns and efforts are required to reduce energy consumption by building energy load. As technologies for environment-friendly alternative energy sources has developed, natural lighting technology using day light has started to develop in view of energy saving. A light-shelf, one of natural lighting methods, introduces day light by reflecting the light to the ceiling in the inside, enabling to reduce energy consumption for lighting during the day time. A light-shelf has high usability due to the excellent constructability and economic feasibility in comparison with other active natural lighting technologies. At present, studies on a light-shelf are limited to simulations and miniaturized models, and the correlations with the angles of a mixed type light-shelf have not been investigated sufficiently. Therefore, the purpose of this study was to investigate the effect of angle adjustment of a mixed type light-shelf on indoor natural lighting and evaluate the 
efficiency of a mixed type light-shelf lighting performance by using an actual size testbed.

\subsection{Methods}

This study was conducted to evaluate the performance of a mixed type light-shelf depending on the angle in an actual size test-bed at summer solstice, winter solstice, vernal equinox, and autumnal equinox by using an artificial solar light of which external illumination may be employed as a set-up variable for each season. The lighting performance of a mixed type light-shelf was evaluated by analyzing the illumination value of the day light introduced to the inside and calculating the average illumination and the uniformity. The study was conducted in the following procedures.

\section{1) Review of Light-Shelf}

Previous studies were reviewed to identify the experimental factors and variables of a light-shelf.

\section{2) Light-Shelf Experimental Setup Variables}

On the basis of previous studies, the illumination values at the meridian transit altitude in each season under clear sky were applied. The light-shelf experimental factors were set up to perform the experiment.

\section{3) Evaluation of Light-Shelf Performance}

Performance evaluation was performed to verify the effectiveness of a light-shelf. The performance evaluation was performed for each season according to the solar altitude of a mixed type light-shelf. The distribution of indoor illumination by the introduced day light was analyzed depending on the angle of the mixed type light-shelf to verify the correlation with variables and the efficacy.

\section{Review on Light-Shelf}

\subsection{Concept of Light-Shelf}

A light-shelf is a light-controlling apparatus which may save lighting energy during day time and increase viewing environment quality by introducing the day light by reflecting it on an indoor ceiling. A light-shelf has advantages in constructability and economic feasibility in comparison with other active natural lighting systems. Lightshelves are classified as three types: internal type, external type, and mixed type.

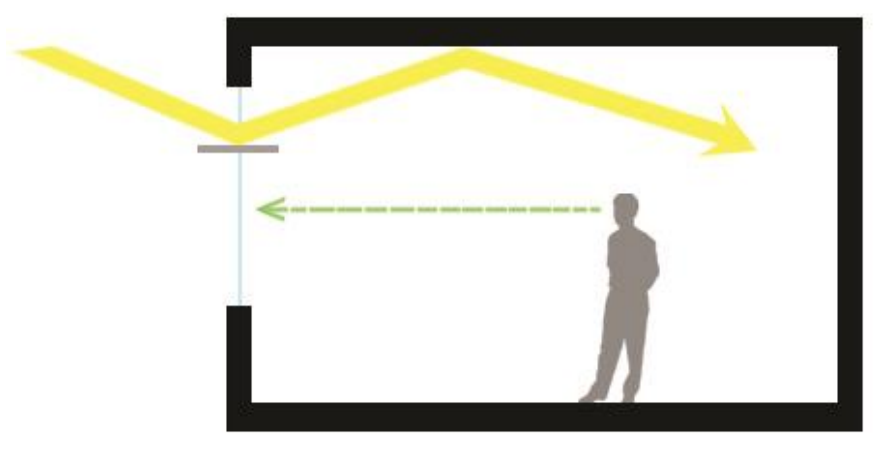

Figure 1. Light-Shelf 


\subsection{Light Shelf Angle Control}

Although an angle-controllable light-shelf is generally more expensive than a fixed type light-shelf, an angle-controllable light-shelf is more flexible in use. When the angle of a light-shelf is tilted downward, the light-shelf shields the windows and thus reduces the amount of light reflected on the ceiling. When the angle of a light-shelf is tilted upwards, penetration of the reflected solar light is increased but the light shielding effect of the windows are reduced. A light-shelf fixed externally may shield more direct solar light introduced through the opening for viewing under the shelf and thus decrease more indoor air conditioning load. A light-shelf fixed internally does not make the top surface of the light shelf be shaded and thus increases the radiant heat of the light introduced through a fan light. Various sensor technologies corresponding to the required conditions are used in collecting spatial information. The information collected by using the technologies are analyzed by an algorithm based on smart lighting control system control logic to derive the optimal values. The finally derived values are put out as the physical performance of light control for effective lighting energy consumption and optimal light environment.

\subsection{Characteristics of Light Shelf}

A light-shelf is generally installed horizontally or nearly horizontally to the inside or outside of a vertical window. A light-shelf should be planned as an integrated factor when a building facade is designed. During a building facade design, not only a lightshelf but also the window system and the ceilings are important factors, and the architectural circumstances of a building to which a light-shelf is to be installed should be taken into account. A light-shelf must be considered in an early stage of construction design because a light-shelf affects the architectural and structural designs of a building and a high ceiling is required to have excellent lighting performance. Although both an internal type and an external type light-shelf may be used under clear sky, an external type light-shelf is more functional in the aspect of shading. A surface finishing having a high reflective ratio is necessary to efficiently reflect the natural light introduced to the inside. On the other hand, when under overcast sky, or in a region where a light-shelf is installed on the windows northwards, an internal type light-shelf or an inclined external type light-shelf is advantageous.

\subsection{Environmental Factors of Light Shelf}

Since light is reflected on a light-shelf to a ceiling and the light reflected on the ceiling is introduced to the inside, the properties of the ceiling affecting the light-introducing procedures are the surface finishing and the tilt angle. A finishing which has a highly reflective surface may reflect more light to the inside. To avoid glare by finishing reflection, a white diffusive material or matte paint is generally used as the finishing. A ceiling which is inclined from the windows heading to the center of a building to the top further increases the light-introducing depth from a light-shelf to the inside. The environmental factors to the performance of a light-shelf include glass materials, which affect the light permittivity of windows, the tilt angle of the ceiling, and the reflective indices of the ceiling finishing, wall finishing, and bottom surface finishing.

\section{Overview on Test-bed Environment for Mixed Type Light-Shelf Performance Evaluation}

\subsection{Overview of Test-bed}

\subsubsection{Test-bed}


This study was conducted to evaluate the performance of a mixed type light-shelf depending on the angle and the size in an actual size test-bed at summer solstice, winter solstice, vernal equinox, and autumnal equinox by using an artificial solar light of which external illumination may be employed as a set-up variable for each season. The lighting performance of a mixed type light-shelf was evaluated by analyzing the illumination values of the day light introduced to the inside, using six internal illumination sensors, and calculating the average illumination and the uniformity. The test-bed was $4.9 \mathrm{~m}$ wide, $6.6 \mathrm{~m}$ deep, and $2.5 \mathrm{~m}$ high to the ceiling. The size of the opening was $2.2 \mathrm{~m}$ wide and 1.8 $\mathrm{m}$ high. The glass material of the opening was $12 \mathrm{~T}$ double glazing.

Table 1. Test-Bed [12]

\begin{tabular}{c|l}
\hline \multicolumn{2}{c}{ Summary of the Test-bed Model } \\
\hline $\begin{array}{c}\text { Room Size and } \\
\text { Material }\end{array}$ & $\begin{array}{l}4.9 \mathrm{~m}(\mathrm{~W}) \times 6.6 \mathrm{~m}(\mathrm{D}) \times 2.5 \mathrm{~m}(\mathrm{H}), \text { Wall : reflectance } 46 \% \text {, Ceiling } \\
\text { : reflectance } 86 \%\end{array}$ \\
\hline $\begin{array}{c}\text { Window Size and } \\
\text { Material }\end{array}$ & $2.2 \mathrm{~m}(\mathrm{~W}) \times 1.8 \mathrm{~m}(\mathrm{H})$, Pair Glass $12 \mathrm{~mm}(3 \mathrm{~mm}+6 \mathrm{~mm}+3 \mathrm{~mm})$ \\
\hline
\end{tabular}

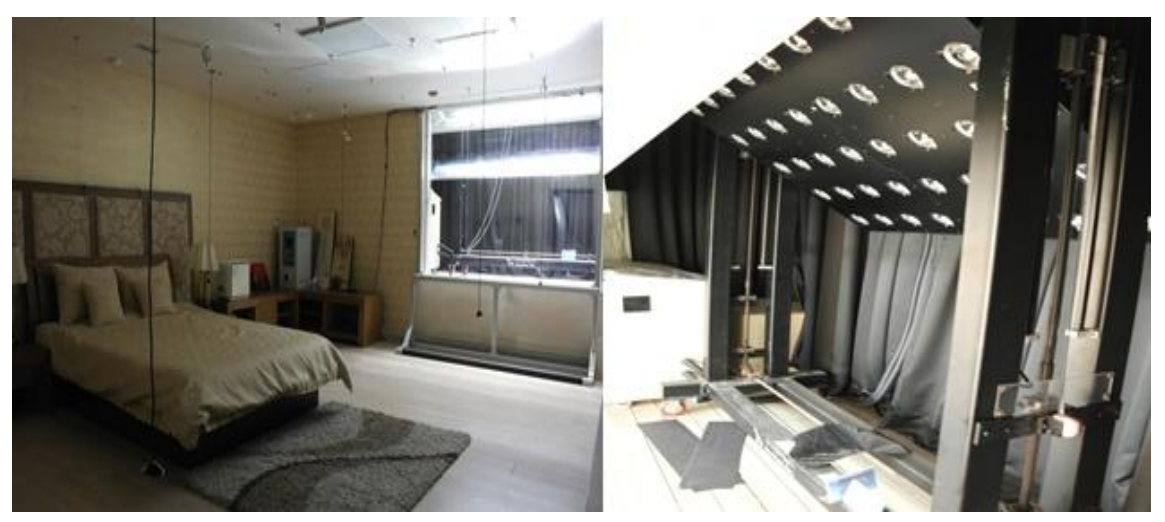

Figure 2. Test-bed and Artificial Sunlight

\subsubsection{Illumination Sensors}

To analyze the introduction of day light to the inside depending on the variables of a light-shelf, illumination sensors were arranged in an interval of $1600 \mathrm{~mm}$ vertically and $1650 \mathrm{~mm}$ horizontally with reference to the windows. The height of the illumination sensors was $450 \mathrm{~mm}$ from the bottom with reference to the working plane of a user on the basis of previous studies.

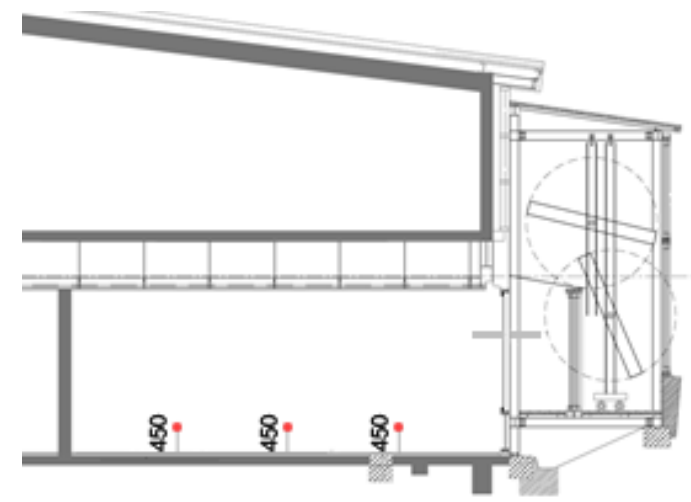

Figure 3. Test-bed and Artificial Sunlight Sectional 


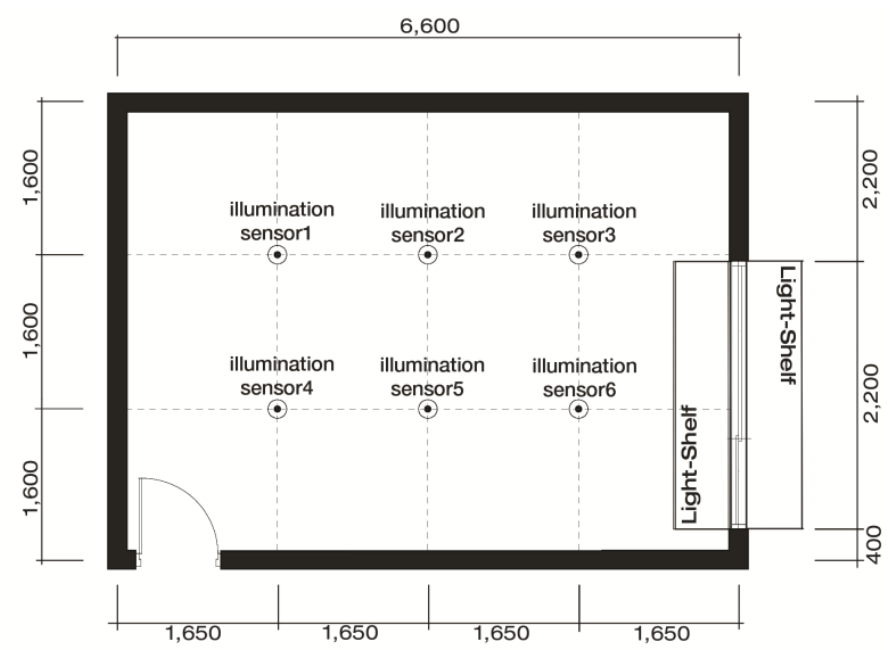

Figure 4. Test-bed and Artificial Sunlight Plan

\subsection{Setup of External Environment and Light-Shelf Variables}

The external environment variables for the experiment were the meridian altitude in each season, which were $76.5^{\circ}$ at the summer solstice, $53^{\circ}$ at the vernal equinox and autumnal equinox, and $29.5^{\circ}$ at the winter solstice. The direction of the building windows was due south. The illumination values for each season were set up as 80,000 lux at the summer solstice, 60,000 lux at the vernal equinox and autumnal equinox, and 30,000 lux at the winter solstice on the basis of previous studies. The height of the light-shelf was set up as $1800 \mathrm{~mm}$ which was higher than the eye level to avoid glare to a person inside the building. The width of an external type light-shelf was set up to be $200 \mathrm{~mm}$. The width of a mixed type light-shelf was $200 \mathrm{~mm}$ for both the inside and the outside. The surface of the light-shelves was finished by using a reflective film having a surface reflection ratio of $85 \%$. In addition, to investigate correlation of the light-shelf tilt angle with the indoor illumination variation and with the light-shelf performance, the tilt angle of the external type light-shelf was varied from $-30^{\circ}$ to $+30^{\circ}$, by $10^{\circ}$ each time, during the experiment. For the mixed type light-shelf, the tilt angle of the outside part was varied from $-30^{\circ}$ to $+30^{\circ}$, by $10^{\circ}$ each time, and that of the inside part was varied from $-30^{\circ}$ to $+30^{\circ}$, by $10^{\circ}$ each time. The external environment variables and the light-shelf variables were set up as follows.

Table 2. Setup of the Experimental Environment [12]

\begin{tabular}{|c|c|c|c|c|}
\hline \multicolumn{2}{|c|}{ Light Shelf System } & \multicolumn{3}{|c|}{ Exterior Environment } \\
\hline $\begin{array}{l}\text { Width of Light } \\
\text { Shelf System } \\
(\mathrm{mm})\end{array}$ & $200 / 200$ & \multicolumn{2}{|c|}{ Culmination Altitude } & $\begin{array}{l}\text { Exterior } \\
\text { Luminance }\end{array}$ \\
\hline Angle & $\begin{array}{l}-30^{\circ},-20^{\circ},+10^{\circ}, 0^{\circ}, \\
+10^{\circ},+20^{\circ},+30^{\circ} \\
\end{array}$ & $\begin{array}{l}\text { Summer } \\
\text { Solstice }\end{array}$ & $\begin{array}{c}76.5 \\
0\end{array}$ & $80,000 \mathrm{~lx}$ \\
\hline $\begin{array}{l}\text { Height of Light } \\
\text { Shelf System } \\
(\mathrm{mm})\end{array}$ & 1800 & $\begin{array}{l}\text { Spring and } \\
\text { Autumnal } \\
\text { Equinoxes }\end{array}$ & $53^{\circ}$ & $60,000 \mathrm{~lx}$ \\
\hline \multirow{2}{*}{$\begin{array}{l}\text { Reflexibility of } \\
\text { Light Shelf } \\
\text { System }\end{array}$} & \multirow{2}{*}{$\begin{array}{l}\text { specular reflection } \\
\text { film (reflexibility } 85 \% \text { ) }\end{array}$} & Winter Solstice & $\begin{array}{c}29.5 \\
\circ\end{array}$ & $30,000 \mathrm{~lx}$ \\
\hline & & Direction & \multicolumn{2}{|c|}{ Full South } \\
\hline
\end{tabular}




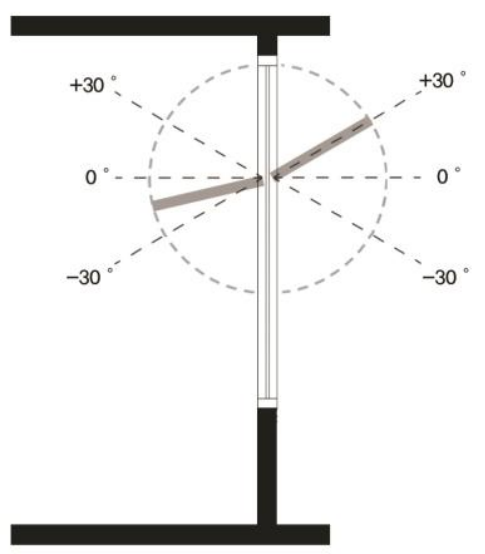

Figure 5. Light-Shelf Angle

\section{Result and Discussion of Light Shelf Performance Evaluation}

To investigate the effectiveness of the lighting performance of a mixed type light-shelf in each season, the illumination values of the day light introduced to the inside were analyzed by using six internal illumination sensors, and the average illumination and the uniformity were calculated. The uniformity was calculated by as Emin/Eave on the basis of previous studies.

\subsection{Performance Evaluation of External Type Light-Shelf}

The performance of the mixed type light-shelf was analyzed by comparing the performance with that of an external type light-shelf. The results of the experiment performed with the external light-shelf are as follows.

Table 3. Result of Performance Evaluation According to the External Type Light Shelf

\begin{tabular}{|c|c|c|c|c|c|c|c|c|c|c|c|}
\hline \multirow{2}{*}{ season } & \multirow{2}{*}{$\underset{t}{\text { heigh }}$} & \multirow{2}{*}{$\begin{array}{c}\text { size } \\
(\mathrm{mm} \\
\text { ) }\end{array}$} & \multirow{2}{*}{$\begin{array}{c}\text { angl } \\
e\end{array}$} & \multicolumn{6}{|c|}{ Sensors(Ix) } & \multirow{2}{*}{$\begin{array}{c}\text { Average } \\
\text { illuminatio } \\
n \\
(\mathrm{Ix}) \\
\end{array}$} & \multirow{2}{*}{$\begin{array}{c}\text { Uniform } \\
\text { ratio of } \\
\text { illumina } \\
\text { nce }\end{array}$} \\
\hline & & & & 1 & 2 & 3 & 4 & 5 & 6 & & \\
\hline \multirow{7}{*}{$\begin{array}{c}\text { summ } \\
\text { er }\end{array}$} & \multirow{7}{*}{1800} & \multirow{7}{*}{200} & -30 & 52 & 348 & 700 & 28 & 552 & 2400 & 680 & 0.0412 \\
\hline & & & -20 & 52 & 344 & $\begin{array}{c}108 \\
0 \\
\end{array}$ & 20 & 544 & 2328 & 728 & 0.0275 \\
\hline & & & -10 & 64 & 364 & $\begin{array}{c}116 \\
4\end{array}$ & 32 & 584 & 2488 & 783 & 0.0409 \\
\hline & & & 0 & 80 & 408 & $\begin{array}{c}128 \\
8 \\
\end{array}$ & 60 & 640 & 2692 & 861 & 0.0697 \\
\hline & & & +10 & $\begin{array}{c}12 \\
4 \\
\end{array}$ & 460 & $\begin{array}{c}139 \\
2 \\
\end{array}$ & 84 & 744 & 3064 & 978 & 0.0859 \\
\hline & & & +20 & $\begin{array}{c}16 \\
8 \\
\end{array}$ & 488 & $\begin{array}{c}132 \\
0\end{array}$ & 160 & 828 & 3012 & 996 & 0.1606 \\
\hline & & & +30 & $\begin{array}{c}21 \\
2 \\
\end{array}$ & 420 & $\begin{array}{c}119 \\
2 \\
\end{array}$ & 164 & 672 & 2752 & 902 & 0.1818 \\
\hline \multirow{6}{*}{$\begin{array}{l}\text { spring } \\
\text { \& } \\
\text { autum } \\
n\end{array}$} & \multirow{6}{*}{1800} & \multirow{6}{*}{200} & -30 & $\begin{array}{c}37 \\
8\end{array}$ & 711 & $\begin{array}{c}150 \\
6\end{array}$ & 345 & $\begin{array}{c}123 \\
9\end{array}$ & 7749 & 1988 & 0.1735 \\
\hline & & & -20 & $\begin{array}{c}38 \\
4\end{array}$ & 720 & $\begin{array}{c}159 \\
6\end{array}$ & 345 & $\begin{array}{c}126 \\
6\end{array}$ & 7923 & 2039 & 0.1692 \\
\hline & & & -10 & $\begin{array}{c}40 \\
5\end{array}$ & 771 & $\begin{array}{c}177 \\
3\end{array}$ & 363 & $\begin{array}{c}131 \\
4\end{array}$ & 8466 & 2182 & 0.1664 \\
\hline & & & 0 & $\begin{array}{c}43 \\
5 \\
\end{array}$ & 834 & $\begin{array}{c}190 \\
8 \\
\end{array}$ & 399 & $\begin{array}{c}143 \\
4 \\
\end{array}$ & 8796 & 2301 & 0.1734 \\
\hline & & & +10 & $\begin{array}{c}47 \\
4 \\
\end{array}$ & 876 & $\begin{array}{c}191 \\
4 \\
\end{array}$ & 444 & $\begin{array}{c}156 \\
0 \\
\end{array}$ & 5808 & 1846 & 0.2405 \\
\hline & & & +20 & $\begin{array}{c}51 \\
0\end{array}$ & 873 & $\begin{array}{c}180 \\
0 \\
\end{array}$ & 558 & $\begin{array}{c}149 \\
4\end{array}$ & 8580 & 2303 & 0.2215 \\
\hline
\end{tabular}




\begin{tabular}{|c|c|c|c|c|c|c|c|c|c|c|c|}
\hline & & & +30 & $\begin{array}{c}53 \\
1 \\
\end{array}$ & 816 & $\begin{array}{c}187 \\
8 \\
\end{array}$ & 591 & $\begin{array}{c}182 \\
1 \\
\end{array}$ & 9051 & 2448 & 0.2169 \\
\hline \multirow{7}{*}{ winter } & \multirow{7}{*}{1800} & \multirow{7}{*}{200} & -30 & $\begin{array}{c}79 \\
2\end{array}$ & $\begin{array}{c}125 \\
3\end{array}$ & $\begin{array}{c}127 \\
9\end{array}$ & $\begin{array}{c}102 \\
2\end{array}$ & $\begin{array}{c}770 \\
4\end{array}$ & 7865 & 3319 & 0.2386 \\
\hline & & & -20 & $\begin{array}{c}81 \\
8\end{array}$ & $\begin{array}{c}129 \\
8\end{array}$ & $\begin{array}{c}156 \\
0\end{array}$ & $\begin{array}{c}102 \\
5\end{array}$ & $\begin{array}{c}776 \\
4\end{array}$ & $\begin{array}{c}1178 \\
4\end{array}$ & 4042 & 0.2025 \\
\hline & & & -10 & $\begin{array}{c}86 \\
6\end{array}$ & $\begin{array}{c}135 \\
6\end{array}$ & $\begin{array}{c}170 \\
9\end{array}$ & $\begin{array}{c}108 \\
2\end{array}$ & $\begin{array}{c}787 \\
2\end{array}$ & $\begin{array}{c}1303 \\
2\end{array}$ & 4320 & 0.2006 \\
\hline & & & 0 & $\begin{array}{c}91 \\
7\end{array}$ & $\begin{array}{c}142 \\
3\end{array}$ & $\begin{array}{c}170 \\
6\end{array}$ & $\begin{array}{c}115 \\
7\end{array}$ & $\begin{array}{c}803 \\
3\end{array}$ & $\begin{array}{c}1307 \\
0\end{array}$ & 4384 & 0.2091 \\
\hline & & & +10 & $\begin{array}{c}95 \\
3\end{array}$ & $\begin{array}{c}140 \\
6\end{array}$ & $\begin{array}{c}155 \\
3\end{array}$ & $\begin{array}{c}123 \\
8\end{array}$ & $\begin{array}{c}795 \\
8\end{array}$ & $\begin{array}{c}1266 \\
0\end{array}$ & 4295 & 0.2218 \\
\hline & & & +20 & $\begin{array}{c}91 \\
9\end{array}$ & $\begin{array}{c}137 \\
3\end{array}$ & $\begin{array}{c}153 \\
1\end{array}$ & $\begin{array}{c}118 \\
1\end{array}$ & $\begin{array}{c}783 \\
8\end{array}$ & $\begin{array}{c}1442 \\
4\end{array}$ & 4544 & 0.2023 \\
\hline & & & +30 & $\begin{array}{c}90 \\
5\end{array}$ & $\begin{array}{c}128 \\
6\end{array}$ & $\begin{array}{c}176 \\
4\end{array}$ & $\begin{array}{c}114 \\
7\end{array}$ & $\begin{array}{c}736 \\
8\end{array}$ & $\begin{array}{c}2109 \\
6\end{array}$ & 5594 & 0.1617 \\
\hline
\end{tabular}

At the summer solstice, the external type light-shelf was directly affected by the artificial solar light. With reference to the No. 4 illumination sensor located at the innermost part, the illumination was the highest as $164 \mathrm{~lx}$ at the upward tilt angle of $+30^{\circ}$ and the uniformity was also the highest as 0.1818 at the same angle of $+30^{\circ}$. At the vernal equinox, with reference to the No. 4 illumination sensor, the illumination was the highest as $519 \mathrm{~lx}$ at the upward tilt angle of $+30^{\circ}$, while the uniformity was the highest as 0.2405 at the angle of $+10^{\circ}$. The uniformity might have been higher because the external type light-shelf played the role of a shade to the high illumination on the window side at the angle of $+10^{\circ}$ at the vernal equinox. At the winter solstice, with reference to the No. 4 illumination sensor, the illumination was the highest as $1238 \mathrm{~lx}$ at the upward tilt angle of $+10^{\circ}$, while the uniformity was the highest as 1.2386 at the downward angle of $-30^{\circ}$. The efficiency was high at the light-shelf tilt angle of $+10^{\circ}$ due to the low solar altitude at the winter solstice. The illumination measured at the No. 6 illumination sensor was low at the downward tilt angle, indicating that the uniformity was the highest at the tilt angle of $-30^{\circ}$ probably because of the shading effect of the light-shelf.

\subsection{Mixed Type Light-Shelf Performance Evaluation}

An experiment was performed with the mixed type light-shelf to evaluate the performance by adjusting the internal and external tilt angles for each season.

\subsubsection{Evaluation of Mixed Type Light-Shelf Performance at Summer Solstice}

At the summer solstice, the mixed type light-shelf was directly affected by the artificial solar light. With reference to the No. 4 illumination sensor located at the innermost part, the illumination of the mixed type light-shelf was the highest as $220 \mathrm{~lx}$ at the internal/external angles of $-30^{\circ} /+20^{\circ},-30^{\circ} \%+30^{\circ},-20^{\circ} \%+30^{\circ}$, and $-10^{\circ} /+30^{\circ}$. The uniformity was the highest as 0.2376 at the angle of $-30^{\circ} \%+30^{\circ}$, at which the lighting performance was also the highest. The efficiency of the mixed type light-shelf at the summer solstice was high at the downward internal angles of $-30^{\circ},-20^{\circ}$, and $-10^{\circ}$, and at the upward external angles of $+20^{\circ}$ and $+30^{\circ}$. When compared with that of the external type light-shelf with reference to the No. 4 illumination sensor, the illumination value of the mixed type light-shelf was higher by $56 \mathrm{~lx}$, and the uniformity of the mixed type light-shelf was also higher by 0.0558 . This showed that the mixed type light-shelf was more advantageous in the deep introduction of day light and in the aspect of uniformity, which represents the quality of light, than that of an external type light-shelf. 
Table 4. Result of Performance Evaluation According to the Mixed Type Light Shelf During Summer

\begin{tabular}{|c|c|c|c|c|c|c|c|c|c|c|c|}
\hline \multirow{2}{*}{ season } & \multirow{2}{*}{ height } & \multirow{2}{*}{$\begin{array}{l}\text { size } \\
(\mathrm{mm})\end{array}$} & \multirow{2}{*}{$\begin{array}{l}\text { Angle } \\
\text { (In/Out) }\end{array}$} & \multicolumn{6}{|c|}{ Sensors(Ix) } & \multirow{2}{*}{$\begin{array}{l}\text { Average } \\
\text { illumination } \\
(\mathrm{Ix})\end{array}$} & \multirow{2}{*}{$\begin{array}{c}\text { Uniform ratio } \\
\text { of } \\
\text { illuminance }\end{array}$} \\
\hline & & & & 1 & 2 & 3 & 4 & 5 & 6 & & \\
\hline \multirow{49}{*}{ summer } & \multirow{49}{*}{1800} & \multirow{49}{*}{$\begin{array}{l}200 / \\
200\end{array}$} & $-30 /-30$ & 100 & 384 & 1084 & 64 & 560 & 2388 & 763 & 0.0838 \\
\hline & & & $-30 /-20$ & 92 & 352 & 1092 & 52 & 552 & 2368 & 751 & 0.0692 \\
\hline & & & $-30 /-10$ & 112 & 384 & 1192 & 68 & 588 & 2512 & 809 & 0.0840 \\
\hline & & & $-30 / 0$ & 144 & 424 & 1344 & 108 & 660 & 2808 & 915 & 0.1181 \\
\hline & & & $-30 /+10$ & 168 & 468 & 1444 & 132 & 768 & 3212 & 1032 & 0.1279 \\
\hline & & & $-30 /+20$ & 220 & 508 & 1328 & 220 & 840 & 3008 & 1021 & 0.2155 \\
\hline & & & $-30 /+30$ & 220 & 448 & 1232 & 220 & 684 & 2752 & 926 & 0.2376 \\
\hline & & & $-20 /-30$ & 84 & 388 & 1128 & 68 & 1032 & 2472 & 862 & 0.0789 \\
\hline & & & $-20 /-20$ & 80 & 388 & 1140 & 68 & 628 & 2468 & 795 & 0.0855 \\
\hline & & & $-20 /-10$ & 92 & 428 & 1224 & 84 & 692 & 2620 & 857 & 0.0981 \\
\hline & & & $-20 / 0$ & 128 & 452 & 1384 & 88 & 732 & 2904 & 948 & 0.0928 \\
\hline & & & $-20 /+10$ & 160 & 488 & 1488 & 124 & 840 & 3300 & 1067 & 0.1163 \\
\hline & & & $-20 /+20$ & 204 & 528 & 1364 & 208 & 908 & 3108 & 1053 & 0.1937 \\
\hline & & & $-20 /+30$ & 223 & 464 & 1252 & 220 & 752 & 2868 & 963 & 0.2284 \\
\hline & & & $-10 /-30$ & 68 & 388 & 1112 & 44 & 620 & 2532 & 794 & 0.0554 \\
\hline & & & $-10 /-20$ & 164 & 392 & 1164 & 72 & 800 & 2732 & 887 & 0.0811 \\
\hline & & & $-10 /-10$ & 180 & 392 & 1240 & 40 & 648 & 2704 & 867 & 0.0461 \\
\hline & & & $-10 / 0$ & 112 & 440 & 1372 & 60 & 792 & 3148 & 987 & 0.0608 \\
\hline & & & $-10 /+10$ & 100 & 492 & 1460 & 105 & 872 & 3352 & 1064 & 0.0940 \\
\hline & & & $-10 /+20$ & 175 & 528 & 1360 & 180 & 912 & 3168 & 1054 & 0.1661 \\
\hline & & & $-10 /+30$ & 240 & 480 & 1288 & 220 & 888 & 3100 & 1036 & 0.2124 \\
\hline & & & $0 /-30$ & 44 & 352 & 1124 & 20 & 568 & 2492 & 767 & 0.0261 \\
\hline & & & $0 /-20$ & 32 & 352 & 1124 & 24 & 568 & 2512 & 769 & 0.0312 \\
\hline & & & $0 /-10$ & 48 & 372 & 1204 & 32 & 604 & 2664 & 821 & 0.0390 \\
\hline & & & $0 / 0$ & 72 & 420 & 1352 & 52 & 668 & 2932 & 916 & 0.0568 \\
\hline & & & $0 /+10$ & 120 & 464 & 1460 & 84 & 780 & 3364 & 1045 & 0.0804 \\
\hline & & & $0 /+20$ & 168 & 504 & 1368 & 168 & 868 & 3168 & 1041 & 0.1614 \\
\hline & & & $0 /+30$ & 148 & 444 & 1272 & 160 & 720 & 2956 & 950 & 0.1558 \\
\hline & & & $+10 /-30$ & 28 & 340 & 1028 & 12 & 552 & 2280 & 707 & 0.0170 \\
\hline & & & $+10 /-20$ & 24 & 344 & 1040 & 12 & 544 & 2312 & 713 & 0.0168 \\
\hline & & & $+10 /-10$ & 28 & 360 & 1128 & 20 & 572 & 2440 & 758 & 0.0264 \\
\hline & & & $+10 / 0$ & 52 & 400 & 1264 & 40 & 644 & 2724 & 854 & 0.0468 \\
\hline & & & $+10 /+10$ & 92 & 452 & 1380 & 72 & 752 & 3148 & 983 & 0.0733 \\
\hline & & & $+10 /+20$ & 144 & 500 & 1280 & 152 & 840 & 2948 & 977 & 0.1473 \\
\hline & & & $+10 /+30$ & 124 & 424 & 1212 & 112 & 664 & 2800 & 889 & 0.1259 \\
\hline & & & $+20 /-30$ & 20 & 328 & 1028 & 12 & 548 & 2092 & 671 & 0.0179 \\
\hline & & & $+20 /-20$ & 28 & 332 & 1028 & 8 & 532 & 2104 & 672 & 0.0119 \\
\hline & & & $+20 /-10$ & 52 & 364 & 1120 & 12 & 584 & 2248 & 730 & 0.0164 \\
\hline & & & $+20 / 0$ & 80 & 400 & 1268 & 44 & 644 & 2528 & 827 & 0.0532 \\
\hline & & & $+20 /+10$ & 112 & 444 & 1364 & 112 & 760 & 2968 & 960 & 0.1167 \\
\hline & & & $+20 /+20$ & 128 & 464 & 1312 & 140 & 824 & 2828 & 949 & 0.1348 \\
\hline & & & $+20 /+30$ & 92 & 412 & 1264 & 68 & 664 & 2720 & 870 & 0.0782 \\
\hline & & & $+30 /-30$ & 20 & 320 & 952 & 20 & 544 & 1852 & 618 & 0.0324 \\
\hline & & & $+30 /-20$ & 12 & 332 & 980 & 20 & 528 & 1880 & 625 & 0.0192 \\
\hline & & & $+30 /-10$ & 32 & 364 & 1052 & 12 & 568 & 2032 & 677 & 0.0177 \\
\hline & & & $+30 / 0$ & 60 & 408 & 1200 & 48 & 640 & 2284 & 773 & 0.0621 \\
\hline & & & $+30 /+10$ & 92 & 460 & 1300 & 68 & 760 & 2720 & 900 & 0.0756 \\
\hline & & & $+30 /+20$ & 108 & 460 & 1232 & 112 & 800 & 2584 & 883 & 0.1224 \\
\hline & & & $+30 /+30$ & 60 & 408 & 1184 & 52 & 648 & 2480 & 805 & 0.0646 \\
\hline
\end{tabular}




\subsubsection{Evaluation of Mixed Type Light-Shelf Performance at Vernal Equinox}

At the vernal equinox, with reference to the No. 4 illumination sensor, the illumination of the mixed type light-shelf was the highest as $885 \mathrm{~lx}$ at the internal/external angle of -30 $\%+30^{\circ}$, followed by $819 \mathrm{~lx}$ and $810 \mathrm{~lx}$ at the internal/external angles of $30^{\circ} /+20$ and $-20^{\circ}$ $1+30$, respectively. The uniformity was the highest as 0.2376 at the angle of $-30^{\circ} /+20$, at which the lighting performance was also high. The efficiency of the mixed type lightshelf at the vernal equinox was high at the downward internal angles of $-30^{\circ}$ and $-20^{\circ}$, and at the upward external angles of $+20^{\circ}$ and $+30^{\circ}$. When compared with that of the external type light-shelf with reference to the No. 4 illumination sensor, the illumination value of the mixed type light-shelf was higher by 294 lx, and the uniformity of the mixed type light-shelf was also higher by 0.0298. This showed that the mixed type light-shelf was more advantageous in the deep introduction of day light and in the aspect of uniformity, which represents the quality of light, than that of an external type light-shelf at the vernal equinox, too.

\section{Table 5. Result of Performance Evaluation According to the Mixed Type} Light Shelf During Spring and Autumn

\begin{tabular}{|c|c|c|c|c|c|c|c|c|c|c|c|}
\hline \multirow{2}{*}{ season } & \multirow[b]{2}{*}{ height } & \multirow{2}{*}{$\begin{array}{c}\text { size } \\
(\mathrm{mm})\end{array}$} & \multirow{2}{*}{$\begin{array}{l}\text { Angle } \\
\text { (In/Out) }\end{array}$} & \multicolumn{6}{|c|}{ Sensors(Ix) } & \multirow{2}{*}{\begin{tabular}{|c|} 
Average \\
illumination \\
(Ix)
\end{tabular}} & \multirow{2}{*}{$\begin{array}{c}\text { Uniform ratio } \\
\text { of } \\
\text { illuminance }\end{array}$} \\
\hline & & & & 1 & 2 & 3 & 4 & 5 & 6 & & \\
\hline \multirow{35}{*}{$\begin{array}{l}\text { spring \& } \\
\text { autumn }\end{array}$} & \multirow{35}{*}{1800} & \multirow{35}{*}{$\begin{array}{c}200 / 20 \\
0\end{array}$} & $-30 /-30$ & 498 & 693 & 1464 & 603 & 1221 & 8046 & 2088 & 0.2386 \\
\hline & & & $-30 /-20$ & 516 & 705 & 1569 & 630 & 1260 & 8280 & 2160 & 0.2389 \\
\hline & & & $-30 /-10$ & 543 & 741 & 1755 & 639 & 1308 & 8784 & 2295 & 0.2366 \\
\hline & & & $-30 / 0$ & 561 & 774 & 1869 & 666 & 1398 & 9066 & 2389 & 0.2348 \\
\hline & & & $-30 /+10$ & 600 & 834 & 1866 & 720 & 1509 & 9099 & 2438 & 0.2461 \\
\hline & & & $-30 /+20$ & 651 & 813 & 1773 & 819 & 1464 & 8928 & 2408 & 0.2703 \\
\hline & & & $-30 /+30$ & 660 & 783 & 1881 & 885 & 1536 & 9390 & 2523 & 0.2616 \\
\hline & & & $-20 /-30$ & 498 & 783 & 1581 & 525 & 1491 & 8376 & 2209 & 0.2254 \\
\hline & & & $-20 /-20$ & 495 & 798 & 1695 & 531 & 1518 & 8595 & 2272 & 0.2179 \\
\hline & & & $-20 /-10$ & 525 & 831 & 1875 & 549 & 1566 & 9120 & 2411 & 0.2178 \\
\hline & & & $-20 / 0$ & 570 & 879 & 1998 & 588 & 1671 & 9420 & 2521 & 0.2261 \\
\hline & & & $-20 /+10$ & 600 & 930 & 1998 & 636 & 1779 & 9423 & 2561 & 0.2343 \\
\hline & & & $-20 /+20$ & 633 & 924 & 1884 & 729 & 1725 & 9204 & 2517 & 0.2515 \\
\hline & & & $-20 /+30$ & 633 & 879 & 1995 & 810 & 1773 & 9675 & 2628 & 0.2409 \\
\hline & & & $-10 /-30$ & 423 & 741 & 1689 & 399 & 1443 & 8736 & 2239 & 0.1782 \\
\hline & & & $-10 /-20$ & 429 & 756 & 1815 & 408 & 1455 & 8958 & 2304 & 0.1771 \\
\hline & & & $-10 /-10$ & 450 & 789 & 1986 & 426 & 1503 & 9414 & 2428 & 0.1755 \\
\hline & & & $-10 / 0$ & 486 & 831 & 2115 & 456 & 1611 & 9738 & 2540 & 0.1796 \\
\hline & & & $-10 /+10$ & 516 & 885 & 2118 & 516 & 1725 & 9615 & 2563 & 0.2014 \\
\hline & & & $-10 /+20$ & 573 & 891 & 2019 & 609 & 1671 & 9564 & 2555 & 0.2243 \\
\hline & & & $-10 /+30$ & 555 & 834 & 2124 & 639 & 1548 & 10086 & 2631 & 0.2109 \\
\hline & & & $0 /-30$ & 381 & 690 & 1734 & 351 & 1275 & 8790 & 2204 & 0.1593 \\
\hline & & & $0 /-20$ & 390 & 696 & 1860 & 351 & 1296 & 9021 & 2269 & 0.1547 \\
\hline & & & $0 /-10$ & 414 & 726 & 2001 & 375 & 1329 & 9378 & 2371 & 0.1582 \\
\hline & & & $0 / 0$ & 444 & 774 & 2118 & 399 & 1437 & 9678 & 2475 & 0.1612 \\
\hline & & & $0 /+10$ & 489 & 828 & 2118 & 459 & 1551 & 9720 & 2528 & 0.1816 \\
\hline & & & $0 /+20$ & 549 & 828 & 2031 & 561 & 1491 & 9516 & 2496 & 0.2200 \\
\hline & & & $0 /+30$ & 489 & 786 & 2184 & 486 & 1455 & 10203 & 2601 & 0.1869 \\
\hline & & & $+10 /-30$ & 339 & 618 & 1599 & 303 & 1104 & 8349 & 2052 & 0.1477 \\
\hline & & & $+10 /-20$ & 360 & 633 & 1704 & 315 & 1128 & 8571 & 2119 & 0.1487 \\
\hline & & & $+10 /-10$ & 384 & 678 & 1890 & 336 & 1185 & 9111 & 2264 & 0.1484 \\
\hline & & & $+10 / 0$ & 420 & 708 & 2004 & 363 & 1284 & 9408 & 2365 & 0.1535 \\
\hline & & & $+10 /+10$ & 459 & 765 & 2025 & 423 & 1404 & 9435 & 2419 & 0.1749 \\
\hline & & & $+10 /+20$ & 495 & 786 & 1959 & 513 & 1386 & 9339 & 2413 & 0.2051 \\
\hline & & & $+10 /+30$ & 426 & 729 & 2094 & 408 & 1416 & 9909 & 2497 & 0.1634 \\
\hline
\end{tabular}




\begin{tabular}{|c|c|c|c|c|c|c|c|c|c}
\hline$+20 /-30$ & 336 & 606 & 1554 & 300 & 1095 & 8013 & 1984 & 0.1512 \\
\hline$+20 /-20$ & 348 & 621 & 1656 & 300 & 1104 & 8220 & 2042 & 0.1470 \\
\hline$+20 /-10$ & 369 & 660 & 1821 & 315 & 1158 & 8676 & 2167 & 0.1454 \\
\hline$+20 / 0$ & 396 & 696 & 1935 & 351 & 1263 & 8979 & 2270 & 0.1546 \\
\hline$+20 /+10$ & 438 & 750 & 1965 & 384 & 1371 & 9039 & 2325 & 0.1652 \\
\hline$+20 /+20$ & 450 & 729 & 1944 & 444 & 1404 & 9099 & 2345 & 0.1893 \\
\hline$+20 /+30$ & 405 & 690 & 2061 & 360 & 1224 & 9549 & 2382 & 0.1512 \\
\hline$+30 /-30$ & 306 & 561 & 1296 & 270 & 1023 & 6858 & 1719 & 0.1571 \\
\hline$+30 /-20$ & 321 & 570 & 1401 & 279 & 1050 & 7104 & 1788 & 0.1561 \\
\hline$+30 /-10$ & 351 & 303 & 1656 & 300 & 1089 & 7608 & 1885 & 0.1592 \\
\hline$+30 / 0$ & 369 & 651 & 1701 & 333 & 1194 & 7884 & 2022 & 0.1647 \\
\hline$+30 /+10$ & 399 & 693 & 1710 & 360 & 1296 & 7941 & 2067 & 0.1742 \\
\hline$+30 /+20$ & 390 & 663 & 1698 & 354 & 1215 & 7959 & 2047 & 0.1730 \\
\hline$+30 /+30$ & 366 & 636 & 1785 & 333 & 1134 & 8391 & 2108 & 0.1580 \\
\hline
\end{tabular}

\subsubsection{Evaluation of Mixed Type Light-Shelf Performance at Winter Solstice}

At the winter solstice, with reference to the No. 4 illumination sensor located at the innermost part, the illumination of the mixed type light-shelf was the highest as $1334 \mathrm{~lx}$ at the internal/external angle of $-20^{\circ} /+10^{\circ}$, followed by $1332 \mathrm{~lx}$ at $-20^{\circ} /+20^{\circ}$. The uniformity was the highest as 0.2793 at the angle of $-10^{\circ} \%-30^{\circ}$. The efficiency of the mixed type light-shelf at the vernal equinox was high at the downward internal angle of $20^{\circ}$, and at the upward external angles of $+10^{\circ},+20^{\circ}$. When compared with that of the external type light-shelf with reference to the No. 4 illumination sensor, the illumination value of the mixed type light-shelf was higher by $96 \mathrm{~lx}$, and the uniformity of the mixed type light-shelf was also higher by 0.0409 . This showed that the mixed type light-shelf was more advantageous in the deep introduction of day light and in the aspect of uniformity, which represents the quality of light, than that of an external type light-shelf at the winter solstice, too.

Table 6. Result of Performance Evaluation According to the Mixed Type Light Shelf During Winter

\begin{tabular}{|c|c|c|c|c|c|c|c|c|c|c|c|}
\hline \multirow{2}{*}{ season } & \multirow{2}{*}{ height } & \multirow{2}{*}{ size $(\mathrm{mm})$} & \multirow{2}{*}{$\begin{array}{l}\text { Angle } \\
\text { (In/Out) }\end{array}$} & \multicolumn{6}{|c|}{ Sensors(Ix) } & \multirow{2}{*}{$\begin{array}{l}\text { Average } \\
\text { illumination } \\
\text { (Ix) }\end{array}$} & \multirow{2}{*}{$\begin{array}{c}\text { Uniform } \\
\text { ratio of } \\
\text { illuminance }\end{array}$} \\
\hline & & & & 1 & 2 & 3 & 4 & 5 & 6 & & \\
\hline \multirow{21}{*}{ winter } & \multirow{21}{*}{1800} & \multirow{21}{*}{$200 / 200$} & $-30 /-30$ & 823 & 1102 & 1217 & 1109 & 7584 & 6691 & 3088 & 0.2666 \\
\hline & & & $-30 /-20$ & 876 & 1157 & 1514 & 1152 & 7649 & 10399 & 3791 & 0.2311 \\
\hline & & & $-30 /-10$ & 895 & 1205 & 1639 & 1212 & 7814 & 11580 & 4058 & 0.2206 \\
\hline & & & $-30 / 0$ & 953 & 1262 & 1603 & 1250 & 7896 & 11486 & 4075 & 0.2338 \\
\hline & & & $-30 /+10$ & 977 & 1250 & 1457 & 1313 & 7814 & 11206 & 4003 & 0.2440 \\
\hline & & & $-30 /+20$ & 950 & 1214 & 1478 & 1310 & 7745 & 12936 & 4272 & 0.2225 \\
\hline & & & $-30 /+30$ & 938 & 1145 & 1694 & 1224 & 7241 & 18528 & 5128 & 0.1830 \\
\hline & & & $-20 /-30$ & 821 & 1123 & 1202 & 1133 & 7627 & 6629 & 3089 & 0.2657 \\
\hline & & & $-20 /-20$ & 869 & 1166 & 1490 & 1159 & 7663 & 10248 & 3766 & 0.2307 \\
\hline & & & $-20 /-10$ & 907 & 1224 & 1620 & 1229 & 7790 & 11570 & 4057 & 0.2236 \\
\hline & & & $-20 / 0$ & 948 & 1284 & 1596 & 1277 & 7910 & 11501 & 4086 & 0.2320 \\
\hline & & & $-20 /+10$ & 979 & 1255 & 1433 & 1334 & 7867 & 11186 & 4009 & 0.2442 \\
\hline & & & $-20 /+20$ & 977 & 1226 & 1445 & 1322 & 7745 & 12929 & 4274 & 0.2286 \\
\hline & & & $-20 /+30$ & 934 & 1164 & 1675 & 1229 & 7231 & 18480 & 5119 & 0.1824 \\
\hline & & & $-10 /-30$ & 845 & 1094 & 1248 & 1169 & 7061 & 6720 & 3023 & 0.2795 \\
\hline & & & $-10 /-20$ & 866 & 1123 & 1550 & 1190 & 7123 & 10308 & 3694 & 0.2346 \\
\hline & & & $-10 /-10$ & 902 & 1181 & 1661 & 1226 & 7236 & 11609 & 3969 & 0.2274 \\
\hline & & & $-10 / 0$ & 955 & 1243 & 1632 & 1310 & 7385 & 11558 & 4014 & 0.2380 \\
\hline & & & $-10 /+10$ & 974 & 1219 & 1478 & 1238 & 7238 & 8798 & 3491 & 0.2790 \\
\hline & & & $-10 /+20$ & 950 & 1190 & 1488 & 1313 & 7193 & 12857 & 4165 & 0.2282 \\
\hline & & & $-10 /+30$ & 938 & 936 & 1718 & 1262 & 7157 & 18480 & 5082 & 0.1842 \\
\hline
\end{tabular}




\begin{tabular}{|c|c|c|c|c|c|c|c|c|c}
\hline & $0 /-30$ & 775 & 1039 & 1351 & 1070 & 6708 & 6890 & 2972 & 0.2608 \\
\hline $0 /-20$ & 809 & 1085 & 1634 & 1092 & 6718 & 10505 & 3640 & 0.2222 \\
\hline $0 /-10$ & 842 & 1133 & 1764 & 883 & 6830 & 11731 & 3864 & 0.2180 \\
\hline $0 / 0$ & 902 & 1190 & 1745 & 1193 & 6967 & 11714 & 3952 & 0.2283 \\
\hline $0 /+10$ & 929 & 943 & 1598 & 1253 & 6888 & 11393 & 3834 & 0.2423 \\
\hline $0 /+20$ & 905 & 914 & 1620 & 1190 & 6818 & 13063 & 4085 & 0.2215 \\
\hline $0 /+30$ & 878 & 1118 & 1807 & 1152 & 6756 & 18574 & 5048 & 0.1740 \\
\hline$+10 /-30$ & 734 & 1013 & 1385 & 1025 & 6617 & 6941 & 2952 & 0.2487 \\
\hline$+10 /-20$ & 763 & 1061 & 1680 & 1058 & 6672 & 10562 & 3633 & 0.2101 \\
\hline$+10 /-10$ & 804 & 1116 & 1802 & 1082 & 6797 & 11904 & 3918 & 0.2052 \\
\hline$+10 / 0$ & 859 & 1169 & 1766 & 1154 & 6890 & 11808 & 3941 & 0.2180 \\
\hline$+10 /+10$ & 878 & 1159 & 1668 & 1212 & 6823 & 11561 & 3884 & 0.2262 \\
\hline$+10 /+20$ & 857 & 893 & 1661 & 1152 & 6768 & 13284 & 4102 & 0.2089 \\
\hline$+10 /+30$ & 845 & 1118 & 1865 & 1135 & 6720 & 18845 & 5088 & 0.1660 \\
\hline$+20 /-30$ & 698 & 967 & 1325 & 1001 & 6530 & 6636 & 2860 & 0.2442 \\
\hline$+20 /-20$ & 734 & 1008 & 1608 & 1027 & 6605 & 10238 & 3537 & 0.2076 \\
\hline$+20 /-10$ & 773 & 1070 & 1754 & 1073 & 6698 & 11587 & 3826 & 0.2020 \\
\hline$+20 / 0$ & 830 & 1116 & 1733 & 1135 & 6821 & 11549 & 3864 & 0.2149 \\
\hline$+20 /+10$ & 818 & 1106 & 1637 & 1142 & 6746 & 11366 & 3803 & 0.2152 \\
\hline$+20 /+20$ & 809 & 1087 & 1613 & 1118 & 6662 & 12950 & 4040 & 0.2002 \\
\hline$+20 /+30$ & 806 & 1075 & 1812 & 1118 & 6665 & 18475 & 4992 & 0.1615 \\
\hline$+30 /-30$ & 655 & 965 & 1193 & 960 & 6504 & 5731 & 2668 & 0.2456 \\
\hline$+30 /-20$ & 686 & 1015 & 1490 & 986 & 6569 & 9413 & 3360 & 0.2043 \\
\hline$+30 /-10$ & 734 & 1068 & 1622 & 1027 & 6679 & 10685 & 3636 & 0.2020 \\
\hline$+30 / 0$ & 768 & 1102 & 1603 & 1073 & 6749 & 10627 & 3654 & 0.2102 \\
\hline$+30 /+10$ & 761 & 1092 & 1526 & 1061 & 6655 & 10440 & 3589 & 0.2120 \\
\hline$+30 /+20$ & 756 & 1070 & 1495 & 1063 & 6638 & 12089 & 3852 & 0.1963 \\
\hline$+30 /+30$ & 758 & 1063 & 1706 & 1061 & 6617 & 17597 & 4800 & 0.1580 \\
\hline
\end{tabular}

\section{Conclusions}

The lighting performance of a mixed type light-shelf was evaluated by investigating the effect of the light-shelf tilt angle on the indoor space. To evaluate the performance of a mixed type light-shelf, the experiment was performed with an external type light-shelf under the same conditions and the results were compared and analyzed. The performance evaluation results are as follows.

First, at the summer solstice, the mixed type light-shelf was directly affected by the artificial solar light. With reference to the No. 4 illumination sensor located at the innermost part, the illumination of the mixed type light-shelf was the highest as $220 \mathrm{~lx}$ at the internal/external angles of $-30 \%+20^{\circ},-30^{\circ} /+30^{\circ},-20^{\circ} \%+30^{\circ}$, and $-10^{\circ} \%+30^{\circ}$. The uniformity was the highest as 0.2376 at the angle of $-30^{\circ} \%+30^{\circ}$, at which the lighting performance was also the highest. The efficiency of the mixed type light-shelf at the summer solstice was high at the downward internal angles of $-30^{\circ},-20^{\circ}$, and $-10^{\circ}$, and at the upward external angles of $+20^{\circ}$ and $+30^{\circ}$. When compared with that of the external type light-shelf with reference to the No. 4 illumination sensor, the illumination value of the mixed type light-shelf was higher by $56 \mathrm{~lx}$, and the uniformity of the mixed type light-shelf was also higher by 0.0558 .

Second, at the vernal equinox, with reference to the No. 4 illumination sensor, the illumination of the mixed type light-shelf was the highest as $885 \mathrm{~lx}$ at the internal/external angle of $-30^{\circ} /+30^{\circ}$, followed by $819 \mathrm{~lx}$ and $810 \mathrm{~lx}$ at the internal/external angles of $-30 \%+20$ and $-20 \%+30$, respectively. The uniformity was the highest as 0.2376 at the angle of $-30 \%+20$, at which the lighting performance was also high. The efficiency of the mixed type light-shelf at the vernal equinox was high at the downward internal angles of $-30^{\circ}$ and $-20^{\circ}$, and at the upward external angles of $+20^{\circ}$ 
and $+30^{\circ}$. When compared with that of the external type light-shelf with reference to the No. 4 illumination sensor, the illumination value of the mixed type light-shelf was higher by $294 \mathrm{~lx}$, and the uniformity of the mixed type light-shelf was also higher by 0.0298 .

Third, at the winter solstice, with reference to the No. 4 illumination sensor located at the innermost part, the illumination of the mixed type light-shelf was the highest as 1334 $1 \mathrm{x}$ at the internal/external angle of $-20^{\circ} /+10^{\circ}$, followed by $1332 \mathrm{~lx}$ at $-20^{\circ} /+20^{\circ}$. The uniformity was the highest as 0.2793 at the angle of $-10^{\circ} /-30^{\circ}$. The efficiency of the mixed type light-shelf at the vernal equinox was high at the downward internal angle of $20^{\circ}$, and at the upward external angles of $+10^{\circ},+20^{\circ}$. When compared with that of the external type light-shelf with reference to the No. 4 illumination sensor, the illumination value of the mixed type light-shelf was higher by $96 \mathrm{~lx}$, and the uniformity of the mixed type light-shelf was also higher by 0.0409 .

At all the summer solstice, vernal equinox, and winter solstice, the mixed type lightshelf was more advantageous in the deep introduction of day light and in the aspect of uniformity, which represents the quality of light, than that of an external type light-shelf. This shows that the mixed type light-shelf had better lighting performance than that of the external type light-shelf due to the function of adjusting the internal/external angles. This study was performed only with the light-shelf having a width of $200 \mathrm{~mm}$. Future studies may need to be conducted to evaluate the light performance of a mixed type light-shelf by investigating the effect of the width and title angle on the indoor space.

\section{References}

[1] H. W. Lee, D. S. Kim and Y. S. Kim, "Performance Evaluation of Light-shelf focused on the Depth of Space and the Dimensions and Angles of Light-shelf", Journal of Architectural Institute of Korea Planning \& Design, vol. 29, no. 3, (2013).

[2] B. K. Kim and J. T. Kim, "Scale Model Experiment for Daylighting Performance by Lightshelf Types", Journal of the Korean Institute of Educational Architecture and Environment, vol. 9, (2005).

[3] J. T. Kim, H. G. Shin and G. Kim, "Design and Performance Evaluation of Horizontal LightRedirecting Devices in Offices", Proceeding of the SAREK Summer Annual Conference, vol. 19, no. 3, (2003).

[4] B. C. Park, Y. S. Kim, K. Y. Jeong and A. S. Choi, "An Fundamental Study on the Interactive System for Daylight Response Dimming System and Environment", vol. 9, (2005).

[5] J. H. Yun, "A Study on the Performance Evaluation of Lightshelf Daylighting system for Educational building", Journal of Architectural Institute of Korea Planning \& Design, vol. 8, no. 1, (2006).

[6] S. J. Kim, "Integrated system of light shelf and venetian blind for improving daylighting performance", (2011).

[7] B. I. Park, "An Analysis of Daylighting Performance of Light Shelf in Office Building", (2008).

[8] Y. G. Chung, "A Study on the Design and Power Performance of a Variable Photovoltaic Lightshelf Mounted on the Windows", (2013).

[9] J. T. Kim, "Visual Performance Evaluation of Daylighting System with Sloped Lightshelves", (2006).

[10] H. W. Lee, "The Improvement of Uniformity Ratio for Luminous Environment Using Horizontal Lightshelf in an Office Building”, (2011).

[11] W. R. Chae, H. W. Lee and Y. S. Kim, "Green Home IT Louver System Survey Book", SISC, Korea, (2012).

[12] W. R. Chae, H. W. Lee and Y. S. Kim, "A Research on Basic Data for the Design of Combined Light Shelves Depending on Internal Angle", Architecture and Civil Engineering, vol. 47, (2014).

\section{Author}

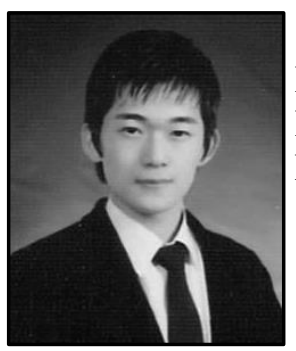

Woori Chae. Master's course, Graduate School of Techno Design Department of Architectural Design, Kookmin University. Researcher, Smart Home Industrialization Support Center by the Ministry of Trade, Industry \& Energy 